DOI: https://doi.org/10.24127/ajpm.v9i1.2660

\title{
CREATIVE PROBLEM SOLVING DAN RESOURCE BASED LEARNING TERHADAP KEMAMPUAN PEMECAHAN MASALAH MATEMATIS DITINJAU DARI GENDER
}

\author{
An Nur Ami Widodo ${ }^{1}$, Sofri Rizka Amalia ${ }^{2}$ \\ ${ }^{1,2}$ Pendidikan Matematika, Universitas Peradaban, Brebes, Indonesia \\ E-mail: $\quad$ amiaqeela@gmail.com ${ }^{1)}$ \\ $\underline{\text { sofri.rizkia@gmail.com }}^{2)}$
}

Received 26 January 2020; Received in revised form 07 March 2020; Accepted 28 March 2020

\begin{abstract}
Abstrak
Tujuan penelitian ini adalah mengetahui (1) kemampuan pemecahan masalah matematis siswa yang diajar dengan model Creative Problem Solving (CPS) dan model Resource Based Learning (RBL) ditinjau dari gender, (2) perbedaan kemampuan pemecahan masalah matematis siswa yang diajar dengan model CPS dan model RBL ditinjau dari gender laki-laki dan perempuan. Penelitian ini merupakan Quasi Eksperimen. Sedangkan desain penelitian yang dipakai dalam penelitian ini adalah Postest Only Control Design. Populasi dalam penelitian ini adalah seluruh kelas VIII di SMP Negeri 3 Margasari. Sampel pada penelitian ini adalah kelas VIII A sebagai kelas model CPS sejumlah 31 siswa, Kelas VIII F sebagai kelas model RBL sejumlah 32 siswa. Teknik pengumpulan data menggunakan tes, dan dokumentasi. Teknik analisis data dalam penelitian ini adalah uji prasyarat analisis yaitu uji normalitas dan uji homogenitas dengan menggunakan SPSS. Uji hipotesis yang dilakukan dalam penelitian ini menggunakan teknik analisis varians dua jalur dan uji independent $t$-test menggunakan SPSS. Hasil penelitian ini adalah (1) tidak terdapat perbedaan yang signifikan kemampuan pemecahan masalah siswa yang diajarkan dengan model CPS dan model RBL, (2) tidak terdapat perbedaan yang signifikan rata-rata kemampuan representasi matematis siswa yang diajar model CPS dan model RBL ditinjau dari gender laki-laki, dan (3) terdapat perbedaan yang signifikan rata-rata kemampuan representasi matematis sisa yang diajar model CPS dan model RBL ditinjau dari gender perempuan.
\end{abstract}

Kata kunci: Creative problem solving; gender, kemampuan pemecahan masalah, resource based learning.

\begin{abstract}
The purpose of this study is to understand (1) the ability to solve mathematical problems of students taught with the Creative Problem Solving (CPS) model and the Resource-Based Learning (RBL) model in terms of gender, (2) solutions to students' mathematical problem solving abilities taught by the CPS model and the RBL model in terms of male and female gender. This research is a Quasi Experiment. While the design used in this study is the Only Posttest Control Design. The population in this study were all class VIII in Margasari 3 Public Middle School. The sample in this study was class VIII As a CPS class model totaling 31 students, Class VIII F as a RBL class model totaling 32 students. Data collection techniques using tests, and regulations. The data analysis technique in this research is the analysis prerequisite test that is normality test and homogeneity test using SPSS. Hypothesis testing conducted in this study uses a two-way variant analysis technique and an independent t-test using SPSS. The results of this study are (1) there is no significant difference between the ability to overcome problems with CPS students and the RBL model, (2) there is no significant difference in the average mathematical representation ability of students taught by the CPS model and the RBL model in terms of male gender men, and (3) the CPS difference model and the RBL model in terms of female gender.
\end{abstract}

Keywords: Creative problem solving; gender, problem solving skills, resource based learning. 
DOI: https://doi.org/10.24127/ajpm.v9i1.2660

\section{PENDAHULUAN}

Hasil PISA (Programme for Internasional Student Assessment) tahun 2018 telah di dirilis OECD (Organisation for Economic Coperation and Development). Rata-rata skor matematika Indonesia sebesar 379. Rata-rata tersebut berada di bawah ratarata OECD yaitu sebesar 489 (OECD, 2019). Hal tersebut menunjukkan kemampuan matematis siswa indonesia masih rendah.

Siswa Indonesia harus meningkatkan kemampuan matematis yang dimiliki. Standar kemampuan matematika yang harus dikuasai adalah: (1) pemecahan masalah; (2) penalaran dan pembuktian; (3) komunikasi; (4) koneksi; dan (5) representasi (NCTM, 2000). Kemampuan pemecahan masalah matematis merupakan salah satu kemampuan yang harus dikuasai.

Pada kenyataannya, kemampuan pemecahan masalah siswa masih rendah. Hal itu diperkuat oleh adanya fakta di lapangan di SMP Negeri 3 Kudus. Siswa mengalami kesulitan dalam memahami soal, menuliskan variabel yang diketahui dalam bahasa matematik, menyusun langkah penyelesaian berdasarkan konsep (Rosita \& Rochmad, 2016). Fakta lain di SMP Negeri 3 Cimahi kelas IX menunjukkan proses pembelajaran yang berpusat pada siswa masih mengalami banyak kendala. Salah satu kendalanya adalah rendahnya kemampuan siswa dalam memecahkan masalah (Komariah, 2011).

Observasi awal dilakukan di SMP Negeri 3 Margasari pada siswa siswa kelas VIII yang terdiri dari VIII A-F. Hasil menunjukkan bahwa kemampuan pemecahan masalah matematis siswa masih rendah yaitu $78 \%$ siswa belum mencapai nilai 65 . Hasil test investigasi menunjukkan bahwa jawaban siswa kurang tepat, siswa kurang memahami masalah yang diberikan. Siswa kurang teliti dalam mengidentifikasikan unsurunsur yang diketahui dalam soal tersebut serta kesalahan dalam menyusun strategi penyelesaian masalah sehingga siswa tersebut salah dalam menjawab soal yang diberikan.

Pemecahan masalah dapat dipandang sebagai suatu bentuk belajar yang mempersyaratkan adanya hal yang baru, yang kelak dapat menjadi dasar bagi siswa agar dapat diaplikasikan dalam masalah baru berikutnya (Sari \& Noer, 2017). Kemampuan pemecahan masalah matematis merupakan suatu kemampuan dalam menyelesaikan masalah menggunakan prosedur yang sesuai.

Berbagai upaya dilakukan pemerintah untuk meningkatkan kemampuan pemecahan masalah siswa. Salah satu model yang dapat digunakan adalah model Creative Problem Solving (CPS). Model CPS merupakan model yang mampu meningkatkan kemampuan siswa dalam berpikir tinggi, karena model ini memberikan kesempatan seluas-luasnya kepada siswa untuk memecahkan masalah matematika dengan caranya sendiri (Saputra \& Mashuri, 2015).

Hal ini sejalan dengan hasil penelitian yang menyebutkan bahwa CPS dapat meningkatkan kemampuan pemecahan masalah matematis siswa (Sari \& Noer, 2017). Hasil penelitian lain menyebutkan bahwa model pembelajaran CPS efektif terhadap kemampuan pemecahan masalah peserta didik di SMP Negeri I Tengaran, dan model pembelajaran CPS lebih efektif dibandingkan model pembelajaran Problem Posing terhadap kemampuan pemecahan masalah peserta didik di SMP Negeri I Tengaran (Fajariyah, Sukestiyarno, \& Junaedi, 
2012). Peningkatan kemampuan pemecahan masalah matematis siswa yang menggunakan model pembelajaran CPS lebih baik daripada siswa yang menggunakan model pembelajaran biasa, sikap siswa terhadap model pembelajaran CPS positif (Muhammad, Septian, \& Sofa, 2018).

Selain model CPS, model Resourse Based Learning (RBL) juga dapat digunakan. Resource-Based Learning guru bukan merupakan sumber belajar satu-satunya, sehingga siswa dapat belajar dalam kelas, dalam laboratorium, dalam perpustakaan, dalam ruang sumber belajar yang khusus atau bahkan di luar sekolah, dalam mempelajari lingkungan berhubungan dengan tugas atau masalah tertentu (Apriliana \& Subanti, 2015). Dengan model tersebut siswa dapat menggunakan dan memilih sumber belajar sesuai kebutuhan.

\section{Penerapan Resource Based}

Learning dan Problem Based Learning efektif terhadap kemampuan pemecahan masalah peserta didik dan penerapan Resource Based Learning lebih baik dari Problem Based Learning (Aliyah, Suyitno, \& Agoestanto, 2014). Penelitian lain menunjukkan bahwa kemampuan pemecahan msalah matematika siswa yang diajarkan dengan menggunakan model pembelajaran Resource Based Learning lebih tinggi daripada kemampuan pemecahan masalah matematika siswa yang diajarkan dengan menggunakan pembelajaran langsung (Ekawati, 2016) Penerapan Resource Based Learning dapat meningkatkan pembelajaran (Alsa, Kusumawati, \& Nuriyatin, 2018). Berdasarkan hasil penelitian terdahulu, model CPS dan RBL dapat digunakan sebagai solusi untuk meningkatkan kemampuan pemecahan masalah.
Kebaruan dalam penelitian ini adalah membandingkan penerapan model CPS dan RBL. Model tersebut diterapkan untuk meningkatkan kemampuan pemecahan masalah siswa di kelas yang diberikan model CPS dan siswa di kelas yang diberikan model RBL. Selain itu, penelitian ini ditinjau dari gender.

Tujuan penelitian ini adalah mengetahui (1) kemampuan pemecahan masalah matematis siswa yang diajar dengan model CPS dan model RBL ditinjau dari gender, (2) perbedaan kemampuan pemecahan masalah matematis siswa yang diajar dengan model CPS dan model RBL ditinjau dari gender laki-laki dan perempuan.

\section{METODE PENELITIAN}

Penelitian ini merupakan Quasi Eksperimen. Sedangkan desain penelitian yang dipakai dalam penelitian ini adalah Postest Only Control Design. Penelitian dilakukan dengan menerapkan model pembelajaran CPS dan RBL pada dua kelas eksperimen. Setelah itu dilakukan posttest untuk mengukur kemampuan pemecahan masalah siswa. Populasi dalam penelitian ini adalah seluruh kelas VIII di SMP Negeri 3 Margasari. Sampel pada penelitian ini adalah kelas VIII A sebagai kelas model CPS sejumlah 31 siswa, Kelas VIII F sebagai kelas model RBL sejumlah 32 siswa.

Teknik pengumpulan data menggunakan tes. Tes dilakukan untuk memperoleh data kemampuan pemecahan masalah matematis siswa. Tes yang dilakukan dalam bentuk esay berjumlah 5 soal. Soal tersebut disesuaikan dengan indikator kemampuan pemecahan masalah matematis polya.

$\begin{array}{ccr}\begin{array}{c}\text { Sebelum } \\ \text { pemecahan }\end{array} & \text { tes } & \text { kemampuan } \\ \text { masalah } & \text { matematis }\end{array}$


diberikan, terlebih dahulu dilakukan uji validitas dan uji reliabilitas. Perhitungan validitas soal uji coba dilakukan dengan menggunakan teknik korelasi product moment. Dari hasil uji validitas menunjukkan bahwa kelima soal dikatakan valid. Perhitungan reliabilitas soal uji coba dilakukan dengan menggunakan Alpha Cronbach. Soal tes kemampuan pemecahan masalah yang diuji coba tersebut reliabel. Sedangkan dokumentasi dilakukan untuk mendapatkan informasi data siswa lakilaki dan perempuan. Teknik analisis data menggunakan uji anava dua jalur.

\section{HASIL DAN PEMBAHASAN}

Setelah kedua sampel diberi perlakuan dengan menggunakan model pembelajaran yang berbeda yaitu CPS dan RBL, maka dilakukan posttest. Dari postest diperoleh data hasil tes kemampuan pemecahan masalah dan selanjutnya dilakukan analisis. Pengujian prasyarat dilakukan adalah sebagai berikut:

\section{Hasil Uji Normalitas}

Uji normalitas data awal kelas sampel dilakukan untuk mengetahui bahwa data sampel dapat mewakili seluruh populasi. Hasil perhitungan uji normalitas dapat dilihat pada Tabel 1 .

Tabel 1. Hasil uji normalitas data awal.

\begin{tabular}{llrcc}
\hline & & \multicolumn{3}{c}{$\begin{array}{c}\text { Kolmogorov- } \\
\text { Smirnov }^{\boldsymbol{a}}\end{array}$} \\
\cline { 3 - 6 } & Kelas & Statistic & Df & Sig. \\
\hline Nilai & Eksperimen & 135 & 31 &, $161^{*}$ \\
UAS & Kontrol &, 128 & 31 &, $200^{*}$ \\
\hline
\end{tabular}

Berdasarkan Tabel 1. diperoleh signifikansi kelas eksperimen $=0,161$ dan kelas kontrol $=0,200$ hal itu berarti nilai signifikansi kelas tersebut lebih dari 0,05 maka $\mathrm{H}_{0}$ diterima. Artinya, data awal kedua kelas berasal dari populasi yang berdistribusi normal.

\section{Hasil Uji Homogenitas}

Uji homogenitas data awal kelas sampel dilakukan untuk mengetahui bahwa kedua kelompok memiliki varians yang sama atau homogen. Hasil uji homogenitas dapat dilihat pada Tabel 2.

Tabel 2. Hasil uji homogenitas data awal

\begin{tabular}{llrr}
\hline & & & \multicolumn{2}{c}{$\begin{array}{l}\text { Levene's Test } \\
\text { for Equality } \\
\text { of Variances }\end{array}$} \\
\cline { 3 - 4 } Nilai & Equal variances & Sig. \\
UAS & 2,39 &, 127 \\
& assumed & 5 &, 1 \\
\cline { 2 - 4 } & $\begin{array}{l}\text { Equal variances } \\
\text { not assumed }\end{array}$ & & \\
\hline
\end{tabular}

Terlihat pada Tabel 2. Diperoleh bahwa nilai sig kelas eksperimen dan kelas kontrol $=0,127$ lebih dari sig 0,05 maka $\mathrm{H}_{0}$ diterima. Artinya, kedua kelas tersebut memiliki varians yang sama.

\section{Perbedaan Kemampuan Pemecahan Masalah matematis yang diajar dengan model CPS dan Model RBL}

Pengujian dilakukan menggunakan uji ANAVA dua jalur dengan bantuan SPSS. Hasil perhitungan dapat dilihat pada Tabel 3. Hasil uji ANAVA dua jalur (Tabel 1) adalah signifikan model $=0,760>\alpha=$ 0,05, maka Ho diterima. Dapat disimpulkan bahwa tidak terdapat perbedaan yang signifikan kemampuan pemecahan masalah siswa yang diajarkan dengan model CPS dan model RBL. Hal tersebut sejalan dengan nilai rata-rata kemampuan pemecahan masalah siswa dengan model CPS yaitu 69,84 yang tidak terlalu jauh rata-rata kemampuan rata-rata siswa dengan model RBL yaitu 69,00. 
DOI: https://doi.org/10.24127/ajpm.v9i1.2660

Tabel 3. Hasil uji ANAVA dua jalur.

Dependent Variable : kemampuan

\begin{tabular}{lrrrrr}
\hline Source & $\begin{array}{c}\text { Type III Sum } \\
\text { of Squares }\end{array}$ & df & \multicolumn{1}{c}{$\begin{array}{c}\text { Mean } \\
\text { Square }\end{array}$} & \multicolumn{1}{c}{$\boldsymbol{F}$} & \multicolumn{1}{c}{ Sig. } \\
\hline Corrected Model & $458,695^{\text {a }}$ & 3 & 152,898 & 6,630 &, 001 \\
Intercept & 291069,473 & 1 & 291069,473 & 12621,943 &, 000 \\
model & 2,164 & 1 & 2,164 &, 094 &, 760 \\
gender & 315,551 & 1 & 315,551 & 13,684 &, 000 \\
model * gender & 136,646 & 1 & 136,646 & 5,926 &, 018 \\
Error & 1360,575 & 59 & 23,061 & & \\
Total & 305361,000 & 63 & & & \\
Corrected Total & 1819,270 & 62 & & & \\
\hline
\end{tabular}

Berdasarkan hasil uji ANAVA dua jalur pada Tabel 3, terlihat bahwa signifikan antara model dengan gender adalah signifikan model $*$ gender $=$ $0,018<\alpha=0,05$. Hal ini mengakibatkan Ho ditolak. Maka dapat disimpulkan bahwa adanya interaksi antara model pembelajaran dengan gender.

Interaksi model pembelajaran dengan gender terjadi karena gender berpengaruh terhadap penggunaan model pembelajaran yang digunaka.
Interaksinya adalah siswa yang laki laki dan perempuan berbeda kemampuan pemecahan masalahan.

\section{Perbedaan Kemampuan Pemecahan Masalah Matematis yang Diajar Model CPS dan Model RBL ditinjau dari Gender Laki-Laki}

Perbedaan kemampuan pemecahan masalah matematis dari gender laki-laki dapat mengguanakan uji independent t-test. Hasil uji beda rata-rata disajikan pada Tabel 4.

Tabel 4. Hasil independent t-test gender laki-laki.

\begin{tabular}{llrrr}
\hline & & \multicolumn{3}{c}{ t-test for Equality of Means } \\
\cline { 3 - 5 } & & \multicolumn{1}{c}{$\boldsymbol{t}$} & $\boldsymbol{d f}$ & Sig. (2-tailed) \\
\hline \multirow{2}{*}{ Kemampuan } & Equal variances assumed & $-1,438$ & 24 &, 163 \\
& Equal variances not assumed & $-1,438$ & 22,406 &, 164 \\
\hline
\end{tabular}

Terlihat pada Tabel 4, output uji independent $t$ test, bahwa nilai signifikan $\quad$ Sig. $=0,163>\alpha=0,05$. Sehingga dapat disimpulkan bahwa tidak terdapat perbedaan yang signifikan rata-rata kemampuan pemecahan masalah matematis siswa yang diajar model CPS dan model RBL ditinjau dari gender laki-laki.

Sedangkan pada siswa laki laki perbedaannya tidak signifikan. Hal ini terlihat dari rata-rata kemampuan pemecahan masalah siswa laki laki pada model CPS sebesar 65,46 dan pada model RBS sebesar 68,08.

Dalam pembelajaran, siswa lakilaki pada model CPS dan RBL menunjukkan bahwa dapat beradaptasi dengan baik dan dapat mengembangkan kemampuannya. Siswa laki-laki dalam pembelajaran model CPS kurang bisa memahami permaslahan sehingga tidak dapat menentukan strategi yang tepat untuk menyelesaikan permasalahannya sendiri. Sedangkan pada pembelajaran model RBL siswa laki laki lebih mudah 
memahami masalah karena menggunakan berbagai sumber belajar yang sesuai. Namun, nilai yang diperoleh masih cukup kecil dibandingkan siswa perempuan.

\section{Perbedaan Kemampuan Pemecahan Masalah Matematis yang Diajar Model CPS dengan model RBL ditinjau dari Gender Perempuan}

Perbedaan kemampuan pemecahan masalah matematis dari gender perempuan dapat mengguanakan uji independent t-test. Hasil uji beda rata-rata pada Tabel 5.
Pada Tabel 5, output uji independent $t$ test, bahwa nilai signifikan Sig. $=0,044<\alpha=0,05$. Sehingga dapat disimpulkan bahwa terdapat perbedaan yang signifikan ratarata kemampuan pemecahan masalah matematis siswa yang diajar model CPS dengn Model RBL ditinjau dari gender perempuan. Pada model CPS siswa perempuan dapat mengembangkan diri lebih baik dibandingkan model RBL. Hal tersebut terlihat dari rata-rata kemampuan pemecahan masalah siswa pada model CPS sebesar 73,00 dan pada model RBS sebesar 69,63.

Tabel 5. Hasil independent t-test gender perempuan.

\begin{tabular}{llcrc}
\hline & & \multicolumn{3}{c}{ t-test for Equality of Means } \\
\cline { 3 - 5 } & & $\boldsymbol{t}$ & $\boldsymbol{d f}$ & \multicolumn{1}{c}{ Sig. (2-tailed) } \\
\hline \multirow{2}{*}{ Kemampuan } & Equal variances assumed & 2,085 & 35 &, 044 \\
& Equal variances not assumed & 2,073 & 32,835 &, 046 \\
\hline
\end{tabular}

Hal tersebut terjadi karena siswa perempuan dalam pembelajaran CPS diberi kesempatan untuk mengemukakan pendapat dalam mencari penyelesaian. Siswa awalnya masih bingung, akan tetapi karena siswa lebih sistematik, tekun dan berusaha keras untuk memahami masalah, maka siswa dapat menentukan berbagai strategi yang cocok untuk menyelesaikan masalah dengan tepat. Siswa yang berkemampuan tinggi dalam kelompok juga sangat membantu siswa lain.

Sedangkan dalam pembelajaran model RBL siswa perempuan aktif mencari sumber lain untuk menyelesaikan permasalahan. Namun, waktu merupakan salah satu faktor yang menjadi kendala dalam pembelajaran. Siswa perempuan terlalu banyak waktu yang terbuang saat mencari sumber di perpustakaan atau sumber lainnya. Hal ini dapat dikurangi dengan mencari sumber belajar sebelum pembelajaran dimulai.

Hal ini sejalan dengan hasil penelitian terdahulu yang menunjukkan bahwa (1) terdapat pengaruh model pembelajaran Problem Solving dalam meningkatkan kemampuan pemecahan masalah peserta didik. (2) Terdapat pengaruh jenis kelamin dalam meningkatkan kemampuan pemecahan masalah peserta didik (Hasanah et al., 2020).

Hasil penelitian Apriani, Djadir, \& Asdar (2018) menyebutkan subjek laki-laki cenderung kesulitan dalam memahami soal pembuatan model matematika dibanding siswa perempuan yang mempunyai usaha lebih dalam pemahaman soal dengan melakukan pemisalan dari soal yang telah diberikan. 


\section{KESIMPULAN DAN SARAN}

Hasil penelitian ini adalah (1) tidak terdapat perbedaan yang signifikan kemampuan pemecahan masalah siswa yang diajarkan dengan model CPS dan model RBL, (2) tidak terdapat perbedaan yang signifikan ratarata kemampuan representasi matematis siswa yang diajar model CPS dan model RBL ditinjau dari gender laki-laki, dan terdapat perbedaan yang signifikan ratarata kemampuan representasi matematis siswa ditinjau dari gender perempuan.

Saran penelitian ini adalah (1) model CPS dan RBL dapat digunakan sebagai solusi untuk meningkatkan kemampuan pemecahan masalah, (2) Model RBL berkaitan dengan berbagai sumber belajar lebih cocok untuk siswa perempuan, sehingga untuk siswa lakilaki dapat diberikan model yang menggunakan aktifitasnya dalam pembelajaran, (3) model CPS dan RBL dapat diterapkan untuk meningkatkan kemampuan matematis lainnya dan dapat ditinjau dari faktor lain selain gender.

\section{DAFTAR PUSTAKA}

Aliyah, U. H., Suyitno, H., \& Agoestanto, A. (2014). Keefektifan Resource Based Learning Terhadap Kemampuan Pemecahan Masalah Peserta Didik Materi Lingkaran. Jurnal Pendidikan Matematika Dan Sains, 2(1), 1018.

https://doi.org/10.15294/ujme.v2i1. 3314

Alsa, E., Kusumawati, I. B., \& Nuriyatin, S. (2018). Penerapan Pendekatan Pembelajaran Resource Based Learning (RBL) pada Materi Pola Bilangan di Kelas VIIIA MTS. Riyadlul Ulum Bangil.
Apriani, E. (2018). Kemampuan Pemecahan Masalah Matematika Ditinjau dari Kemampuan Awal Matematika dan Perbedaan Gender. Jurnal Issues in Mathematics Education (IMED), 1(1), 7-11.

Apriliana, A., \& Subanti, S. (2015). Eksperimentasi Model Pembelajaran Resource Based Learning (RBL) dan Problem Based Learning (PBL) Ditinjau Dari Kemampuan Komunikasi Matematik Peserta Didik Kelas Xi Sma Sekabupaten Kudus Tahun 2013 / 2014. Jurnal Elektronik Pembelajaran Matematika, 3(5), 483-494.

Ekawati. (2016). Pengaruh Model Pembelajaran Resource Based learning (RBL) terhadap Kemampuan Pemecahan Masalah Matematika Siswa. In Universitas Negeri Gorontalo.

Fajariyah, N. I., Sukestiyarno, Y. L., \& Junaedi, I. (2012). Efektivitas Pembelajaran Matematika Dengan Metode Problem Posing Berbasis Pendidikan Karakter. Unnes Journal of Mathematics Education., 1(1), 22-28. https://doi.org/10.15294/ujme.v1i1. 255

Hasanah, S., Supriadi, N., Wahyu, R., \& Putra, Y. (2020). Penerapan Problem Solving Berbantuan Lead Aq Untuk Meningkatkan Kemampuan Pemecahan. Seminar Nasional Matematika Dan Pendidikan Matematika, 2, 141152.

Komariah, K. (2011). Penerapan Metode Pembelajaran Problem Solving Model Polya Untuk Meningkatkan Kemampuan Memecahkan Masalah Bagi Siswa Kelas IX J. Seminar Nasional 
DOI: https://doi.org/10.24127/ajpm.v9i1.2660

Penelitian Pendidikan Dan

Penerapan MIPA, 181-218.

Muhammad, G. M., Septian, A., \& Sofa, M. I. (2018). Penggunaan Model Pembelajaran Creative Problem Solving untuk Meningkatkan Kemampuan Pemecahan Masalah Matematis Siswa. Mosharafa: Jurnal Pendidikan Matematika, 7(3), 315-326.

https://doi.org/10.31980/mosharafa .v7i3.140

OECD. (2019). PISA 2018 Results (Volume I): What Students Know and Can Do, PISA: Vol. I. OECD Publishing.

https://doi.org/https://doi.org/10.17 87/5f07c754-en

Rosita, D., \& Rochmad. (2016). Analisis Kesalahan Siswa Dalam Pemecahan Masalah Ditinjau Dari Adversity Quotient Pada Pembelajaran Creative Problem Solving. Unnes Journal of Mathematics Education Research (UJMER), 5(2), 106-113. http://journal.unnes.ac.id/sju/index. php/ujmer

Saputra, M. F. A., \& Mashuri. (2015). Komparasi Kemampuan Pemecahan Masalah antara Pembelajaran Creative Problem Solving dan Problem Posing. Unnes Journal of Mathematics Education, 4(1), 50-58.

Sari, A. D., \& Noer, S. H. (2017). Kemampuan Pemecahan Masalah Matematis Dengan Model Creative Problem Solving (Cps) Dalam Pembelajaran Matematika. Prosiding, 245-252. 